\title{
Potential Sources of Resistance in U.S. Cucumis melo PIs to Crown Rot Caused by Phytophthora capsici
}

\author{
Ryan S. Donahoo ${ }^{1}$ \\ U.S. Department of Agriculture-Agriculture Research Service, U.S. \\ Vegetable Laboratory, 2700 Savannah Highway, Charleston, SC 29414
}

William W. Turechek

U.S. Department of Agriculture-Agriculture Research Service, U.S. Horticultural Research Laboratory, Ft. Pierce, FL 34945

Judy A. Thies and Chandrasekar S. Kousik ${ }^{2}$

U.S. Department of Agriculture-Agriculture Research Service, U.S. Vegetable Laboratory, 2700 Savannah Highway, Charleston, SC 29414

Additional index words. cucurbit, melon, host plant resistance, oomycete, Phytophthora capsici

Abstract. Phytophthora capsici is an aggressive pathogen that is distributed worldwide with a broad host range infecting solanaceous, fabaceous, and cucurbitaceous crops. Over the past two decades, increased incidence of Phytophthora blight, particularly in eastern states, has threatened production of many vegetable crops. Cucumis melo L. (honeydew and muskmelon), although especially susceptible to fruit rot, is also highly susceptible to crown rot. Currently, little is known about host resistance to $P$. capsici in C. melo. To assess crown rot resistance in $C$. melo seedlings, 308 U.S. PIs, and two commercial cultivars (Athena and Dinero) were grown under greenhouse conditions. Seedlings with three to four true leaves were inoculated with a five-isolate zoospore suspension $\left(1 \times 10^{4}\right.$ zoospores per seedling $)$ at the crown and monitored for 6 weeks. All the susceptible control plants of Athena died within 7 days post-inoculation. The majority of the PIs (281 of 308) were highly susceptible to crown rot and succumbed to the disease rapidly and had less than $20 \%$ of the plants survive. Several PIs (PI 181748, PI 182964, and PI 273438) succumbed to crown rot earlier than the susceptible melon cultivars. Eighty-seven PIs selected on the basis of the first screen were re-evaluated and of these PIs, 44 were less susceptible than cultivars Athena and Dinero. Twenty-five of the 87 PIs were evaluated again and of these six PI, greater than $80 \%$ of the plants survived in the two evaluations. Disease development was significantly slower on these PIs compared with the susceptible checks. High levels of resistance in $S_{1}$ plants of PI 420180, PI 176936, and PI 176940 were observed, which suggests that development of resistant germplasm for use in breeding programs can be accomplished. Further screening and careful selection within each of these PIs can provide a framework for the development of resistant germplasm for use in breeding programs.

The stramenopile plant pathogen Phytophthora capsici Leon. causes root, crown, and fruit rot on a large number of high-value vegetable crops (Granke et al., 2012; Hausbeck and Lamour, 2004). Initially described by Leonian as a pathogen of chili peppers, the pathogen is also known to cause crown and

Received for publication 17 Oct. 2012. Accepted for publication 1 Jan. 2013.

We acknowledge Louise Cauthen, Jennifer Ikerd, and Kim Alford for their assistance with greenhouse experiments.

Mention of a trademark name or proprietary product does not constitute a warranty or guarantee by the U.S. Department of Agriculture nor does it imply exclusion of other products that may also be suitable.

${ }^{1}$ Present address: University of Florida, IFAS SWFREC, Immokalee, FL 34142.

${ }^{2}$ To whom reprint requests should be addressed; e-mailshaker.kousik@ars.usda.gov.

southwest and west-central Florida where the symptoms included fruit rot, water-soaked lesions on leaves, and dieback of shoot tips (McGovern et al., 1993). In a recent evaluation of commercial rootstocks for melon, all the rootstocks including a commercial melon cultivar were highly susceptible to crown rot caused by $P$. capsici (Kousik and Hassell, 2011). Recently, Hausbeck et al. (2012) reported that crowns and stems of muskmelon (cantaloupe) in Michigan were susceptible to natural infection by $P$. capsici and the first noticeable sign of the disease was water soaking of the crown and roots. Although crown rot has been observed in the United States and other parts of the world, fruit rot is generally more common on melons (Ando et al., 2009; Gevens et al., 2008; McGrath, 1996; Thompkins and Tucker, 1937).

Managing $P$. capsici has become more difficult since the loss of the soil fumigant methyl bromide. It was expected that with the loss of methyl bromide, soilborne plant pathogens such as $P$. capsici will become more prevalent forcing growers to use more fungicides to manage disease (Lynch and Carpenter, 1999; Osteen, 2003). Loss of methyl bromide also raises the potential for increasing incidence of crown rot in cucurbits including melons. Several established as well as new fungicides have been reported to be effective against $P$. capsici on vegetable crops (Babadoost and Islam, 2003; Hausbeck et al., 2012; Hausbeck and Lamour, 2004; Kousik et al., 2011; Matheron and Porchas, 2000). Historically, one of the most effective fungicides against $P$. capsici has been mefenoxam, but resistance to mefenoxam also has been well documented from most states in the United States (French-Monar et al., 2006; Granke et al., 2012; Hausbeck and Lamour, 2004; Keinath, 2007; Lamour and Hausbeck, 2000). Recently, resistance in $P$. capsici to the fungicide cyazofamid was reported (Jackson et al., 2012; Kousik and Keinath, 2008). Therefore, alternative strategies to manage $P$. capsici on vegetable crops are needed.

Use of host-plant resistance to manage diseases is probably the most economical and environmentally friendly strategy. Screening of PIs and commercial rootstocks has allowed for the identification of crown rot resistance in Cucurbita pepo (squash) and Lagenaria siceraria (bottle gourd), which are being used in squash breeding and watermelon grafting programs, respectively (Chavez et al., 2011; Kousik et al., 2012; Kousik and Thies, 2007; Padley et al., 2008). A Korean pumpkin cultivar was reported to have high levels of resistance to crown rot caused by $P$. capsici (Lee et al., 2001). Although many studies have indicated that muskmelon plants are susceptible to Phytophthora capsici, resistance to crown rot has not yet been described. Thus, the objectives of the present study were to evaluate 308 PIs of $C$. melo for resistance to crown rot caused by $P$. capsici and to identify and confirm potential sources of resistance.

\section{Materials and Methods}

Seed sources. Seeds representing 318 PIs of $C$. melo (mixed types) were obtained from the USDA, ARS North Central Regional 
Table 1. Percent survivors of 308 Cucumis melo PIs on inoculation with Phytophthora capsici in the initial seedling screen.

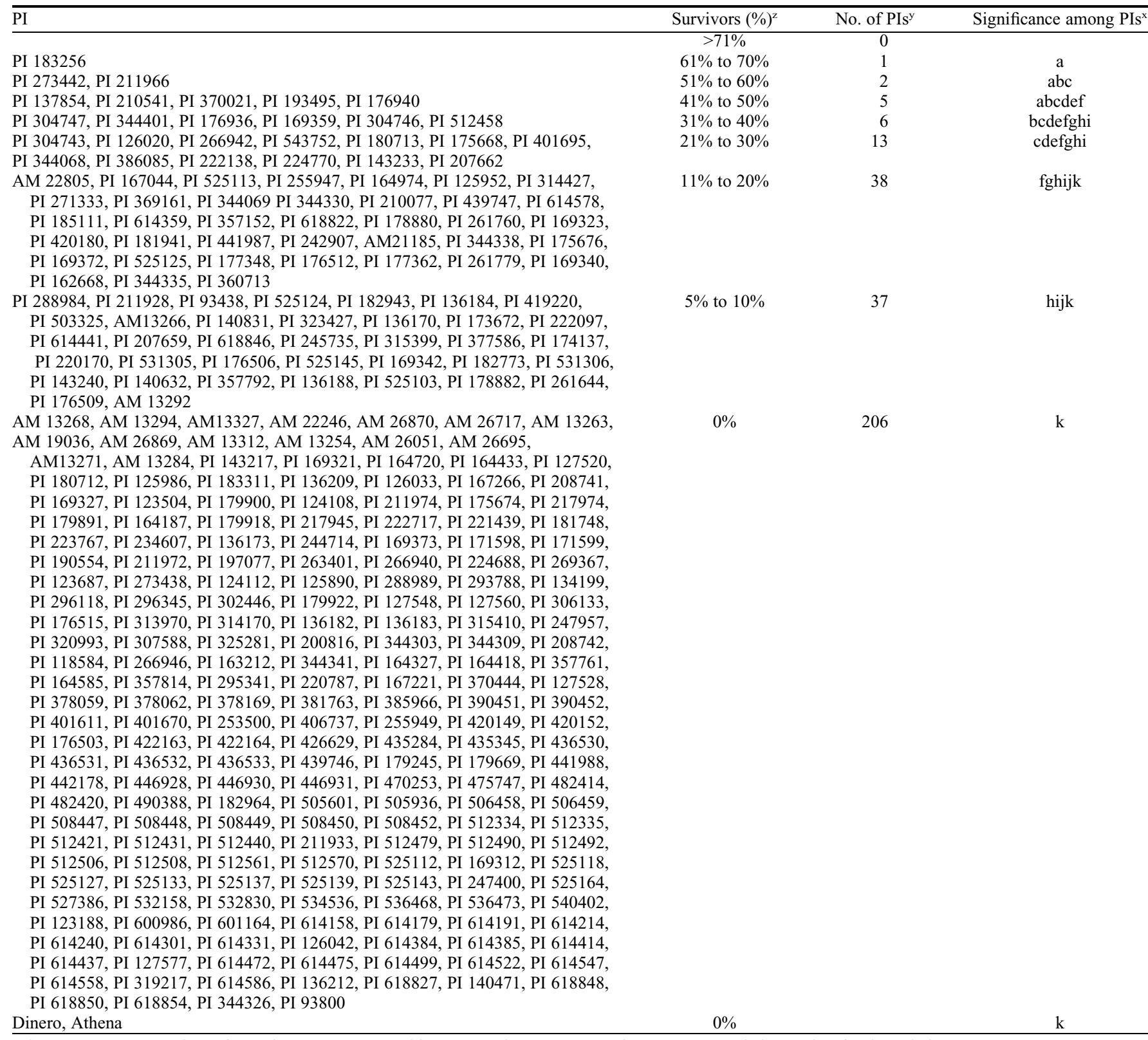

${ }^{\mathrm{z}}$ The mean percent survivors for each PI were separated into categories. Percent survivors were recorded 6 weeks after inoculation.

${ }^{y}$ Indicates number of PIs in each category.

${ }^{x}$ PIs followed by the same letter in column are not significantly different based on Fisher's protected least significant difference $(P=0.05)$.

Plant Introduction Station (NCRPIS), in Ames, IA. Additional information regarding individual C. melo PIs is available at http:// www.ars-grin.gov. Seeds of cultivars Athena and Dinero (Rogers/Syngenta Seed Inc., Boise, ID) used as potential susceptible checks were provided by Dr. R. Hassel (Clemson University, SC). The cultivar Dinero is a rootstock used in melon grafting.

Fungal isolate and inoculum preparation. Isolates of $P$. capsici used in this study were recovered from infected peppers (Capsicum annuum, LJ-9 and LP-44, mating type A2), zucchini squash (Cucurbita pepo, RCZ-11 and RCS-19, mating type A2), watermelon (Citrullus lanatus, WLB-8, mating type A1), and melon (C. melo, cantaloupe, MWM-1, mating type A2) in South Carolina between 2003 and 2011. Isolates were maintained on
Campbell's V8 juice agar (V8A) (Erwin and Ribeiro, 1996). All the isolates used in this study were confirmed as $P$. capsici based on morphology and by polymerase chain reaction (Ristaino et al., 1998; Zhang et al., 2006). For the initial, second, and third seedling screens described below, inoculum was prepared for each of the five isolates by transferring three 7-mm plugs of actively growing mycelia onto two $150 \mathrm{~mm} \mathrm{V8A}$ plates per isolate. Plates were incubated at room temperature $\left(25 \pm 2{ }^{\circ} \mathrm{C}\right)$ under fluorescent lights with a 12-h photoperiod for 5 to $7 \mathrm{~d}$. Plates were flooded with $150 \mathrm{~mL}$ refrigerated $\left(4 \pm 1^{\circ} \mathrm{C}\right)$ sterile, $2^{\prime}, 3^{\prime}$-dideoxyinosine $\mathrm{H}_{2} \mathrm{O}$ and sporangia were dislodged with a sterile loop. The resulting suspension was collected in 1-L flasks. After $30 \mathrm{~min}$, when zoospores were observed, suspensions were passed through two layers of paper tissue (Kimwipe; Kimberly-Clark, Roswell, GA) to eliminate sporangial/mycelial fragments. The flooding/dislodging process was repeated once, at which point the sporangial suspension was allowed to warm to room temperature $\left(25 \pm 2{ }^{\circ} \mathrm{C}\right)$. Three aliquots from the resulting zoospore suspension were vortexed at high speed for $1 \mathrm{~min}$ and the resulting encysted zoospores were quantified with a light microscope using a hemacytometer. The zoospore suspensions for each isolate were adjusted to $1 \times 10^{4}$ zoospores $/ \mathrm{mL}$. Suspensions from each of the five isolates were then gently combined in 2 -L flasks. Inoculations in all experiments were done by pipetting $1 \mathrm{~mL}$ of the $1 \times 10^{4}$ zoospore $/ \mathrm{mL}$ suspension at the crown of the seedling. For the final experiments to confirm resistance in 
Table 2. Test statistics (ANOVA-type statistics) for the effects of Cucumis melo PIs and time on the severity of Phytophthora capsici crown rot in two greenhouse experiments conducted in Charleston, SC.

\begin{tabular}{lrccc}
\hline & \multicolumn{4}{c}{$\begin{array}{c}\text { ANOVA-type statistic } \\
(\text { ATS })^{\mathrm{z}}\end{array}$} \\
\cline { 2 - 5 } Effect & $\mathrm{d} f_{\mathrm{N}}$ & $\mathrm{d} f_{\mathrm{D}}$ & $F$ & $P$ value \\
\hline Seedling screen $2^{\mathrm{y}}$ & & & & \\
$\quad$ PI & 42.46 & 103.29 & 4.92 & 0.0001 \\
$\quad$ Time (T) & 3.81 & $\infty$ & $\infty$ & 0.0001 \\
$\quad$ PI $\times$ T & 89.42 & $\infty$ & 2.42 & 0.0001 \\
Seedling screen 3 & & & & \\
$\quad$ PI & 13.29 & 40.59 & 10.08 & 0.0001 \\
Time (T) & 4.35 & $\infty$ & $\infty$ & 0.0001 \\
PI $\times$ T & 40.11 & $\infty$ & 2.87 & 0.0001 \\
\hline
\end{tabular}

${ }^{\mathrm{z}}$ Analysis of variance-type statistic (ATS) was calculated using nonparametric methods as described by Shah and Madden (2004). $\mathrm{d} f_{\mathrm{N}}=$ numerator $\mathrm{df}, \mathrm{d} f_{\mathrm{D}}=$ denominator df.

${ }^{y}$ In both greenhouse experiments, there were four replications with four plants per replication for each PI). In seedling screen 2, plants of 87 PIs were screened. Six disease ratings recorded on a 0 to 5 scale were used in the analysis. In seedling screen 3, 25 PIs plus two checks were screened and plants were rated eight times on a 0 to 5 scale.

$\mathrm{S}_{1}$ generation, the inoculum suspensions of three isolates (one each from melon, watermelon, and zucchini squash) were used independently and a mixture of five isolates was also used as the inoculum.

Initial seedling screen. Seedlings were grown in $6.4-\mathrm{cm}$ square pots $\left(2 \frac{1}{2}{ }^{\prime \prime}\right.$ Kord TRAD SQ Green; Kord Products, Toronto, Canada) containing Metro Mix 360 (Sun Gro Horticulture, Canada). Sixteen seeds for each PI and the commercial cultivars Athena and Dinero were seeded and maintained on greenhouse benches. The greenhouse was maintained at $26 \pm 2{ }^{\circ} \mathrm{C}$ with normal day/ night light conditions prevailing in Charleston, SC. Experimental treatments (PIs) were arranged in randomized complete block design with two replications. Each PI had eight seedlings per replication with one seedling per pot. After three to four leaves emerged, seedlings were inoculated by pipetting $1 \mathrm{~mL}$ of the five zoospore suspension at the crown. Seedling trays were placed in water-filled reservoirs to keep the plants under water saturated conditions to enhance crown rot development, as described before (Kousik et al., 2012). After $72 \mathrm{~h}$, the plants were removed from the reservoirs. The plants were then placed on greenhouse benches and watered once daily. After 6 weeks, the number of surviving plants was recorded. Only plants that were growing and had new leaf growth without any symptoms were considered as survivors. A total of 308 PIs were scored for percent survivors.

Second and third seedling screens. Based on the initial seedling screen, 87 PIs with $10 \%$ or more survivors were selected for further screening in the greenhouse. The seedlings were grown as described before. Experimental treatments (PIs) were arranged in randomized complete block design with four replications. Each PI had four seedlings per replication with a single seedling per pot.
Plants were inoculated as described previously. Plants were observed daily and rated twice a week for a total of six times using a 0 to 5 scale $(0=$ no symptoms/healthy seedling, 1 = water-soaked hypocotyl, 2 = minor stem/hypocotyl necrosis, $3=$ moderate stem necrosis but no wilting, $4=$ severe stem necrosis with wilting of plant but plant not dead, and $5=$ plant dead).

Based on the second seedling screen, 14s PI that had greater than $80 \%$ survivors and seven PIs from the second screen having 50\% to $78 \%$ survivors were selected for an additional screen. Plants of cultivars Athena and Dinero were included as the susceptible checks. Two PIs that were very susceptible in the second seedling screen were also included in this study. These two PIs were included to determine if these could be used as highly susceptible checks in future experiments. The plants were grown as described before. Experimental treatments (PIs) were arranged in randomized complete block design with four replications. Plants were inoculated and rated twice a week using the 0 to 5 scale, as described before. The first rating was recorded 1 week after inoculation and continued for 4 weeks.

Confirming resistance in $S_{1}$ generation. After the second seedling screen, resistant plants from several of the PIs were transferred to large pots (11.3 L, Classic 1200; Nursery Supplies Inc., Fairless Hills, PA) filled with Metro Mix 360 (Sun Gro Horticulture). The female flowers were handpollinated using pollen from male flowers from the same plant to develop homozygous resistant populations. $S_{1}$ seed from resistant plants of PI 176936, PI 176940, PI 420180 , and PI 266942 were used in this study to determine the potential for development of resistant germplasm lines. Plants were grown as described previously. Each PI was sown in 6.4-cm (2.5-in) square pots filled with Metro Mix 360. Each PI had four replications with four plants in each replication. Three $P$. capsici isolates, one from melon (MWM-1), one from watermelon (WLB-8), and one from zucchini squash (RCZ-11), were used as inoculum in three separate experiments. In addition, a mixture of five $P$. capsici isolates prepared as described before was used in another experiment as the inoculum to further confirm resistance in the $S_{1}$ generation of the selected PI. The plants were inoculated as previously described. The plants were rated on the same 0 to 5 scale twice a week starting from $4 \mathrm{~d}$ after inoculation for a total of 6 weeks.

Data analysis. The data on percent survivors from the initial seedling screen from two replications were arcsine transformed and analyzed using PROC GLM procedure of SAS (Version 9.1; SAS Institute, Cary, NC). Means were separated using Fisher's protected least significant difference $(P=0.05)$.

The crown rot ratings collected for each melon PI over time in the second and third seedling screens were analyzed as repeated-measures data using the nonparametric analysis as previously described (Brunner et al., 2002;
Shah and Madden, 2004). The analysis was performed using the SAS macro F1_LD_F1 to determine the effect of PI, time, and its interaction on the severity of crown rot on the various melon PIs. The SAS macro LD_CI was used to obtain estimates of the relative treatment effects (RTE) and rank means. The macros can be obtained from the web site of E. Brunner at the University of Göttingen, Germany (<http://www.ams.med.uni-goettingen. $\mathrm{de} / \mathrm{de} /$ sof/ld/makros.html $>$ ). The macro F1_LD_F1 was used to calculate the analysis of variance-type statistic (ATS) to test for the overall effect of a factor on crown rot severity and for testing pairwise comparisons of the relative treatment effects within factors (Akritas and Brunner, 1997; Brunner et al., 2002). Detailed descriptions of the statistical methods are provided by Shah and Madden (2004). The overall ranks and RTEs for the PIs were arranged in ascending order and compared using individual pairwise contrasts. The ranks were considered significantly different from each other if the calculated $P$ value for each contrast was $\leq 0.05$.

\section{Results}

Initial seedling screen. In the first screen, a total of 318 C. melo PIs were seeded; however, 308 were evaluated for resistance to crown rot. Seeds from 10 of the 318 PIs did not germinate. Significant $(P \leq 0.0001)$ differences existed among the PIs for their response to crown rot. The majority of accessions (281 of 308) were highly susceptible to crown rot and succumbed rapidly. Most of these had less than $20 \%$ of the plants survive the test. For 206 PIs, there were no survivors at the end of the experiment (Table 1). Some of the PIs (PI 181748, PI 182964, and PI 273438) appeared to be more susceptible than the cultivars Athena and Dinero. Twenty-seven PIs had significantly more survivors than the control (Table 1). At least one individual plant within each of the 308 PIs succumbed to crown rot in this trial. Fourteen PIs had over 31\% survivors in this trial. Based on results of the initial seedling screen, a total of 87 PIs, including 14 PIs with over $31 \%$ survivors and highly susceptible checks, were selected for the second seedling screen.

Second seedling screen. ATS) indicated that significant differences $(P \leq 0.0001)$ existed among the 87 PIs for response to crown rot over time $(\mathrm{PI} \times \mathrm{T})$ in the second seedling screen (Table 2). Of the 87 PIs, 44 scored better than the susceptible checks 'Athena' and 'Dinero'. The plants of the susceptible control 'Athena' succumbed to crown rot within 1 week after inoculation (Table 3). Disease development was significantly slower on the other susceptible control cultivar Dinero compared with 'Athena'; however, by end of the experiment, all plants died. Fourteen PIs had greater than $80 \%$ of the plants survive, and of these, six PIs had greater than $90 \%$ of the plants survive. The five most resistant PIs in this screen were PI 
Table 3. Development of crown rot over time (Rank mean), relative treatment effects (RTE), average final rating and number of survivors of Cucumis melo PIs inoculated with Phytophthora capsici. ${ }^{\mathrm{z}}$

\begin{tabular}{|c|c|c|c|c|c|c|c|c|c|c|c|}
\hline PI & Rank mean $^{y}$ & RTE & & Rating $(1-5)^{x}$ & Survivors $(\%)^{\mathrm{w}}$ & PI Introduction & Rank mean & RTE & & Rating (1-5) & Survivors $(\%)$ \\
\hline$\overline{\text { PI } 176940}$ & 365 & 0.178 & $\mathrm{a}$ & 1.78 & 100 & PI 525118 & 1017 & 0.497 & $\mathrm{f}-\mathrm{k}$ & 3.70 & 53 \\
\hline PI 344069 & 417 & 0.204 & $\mathrm{a}$ & 2.05 & 94 & PI 136184 & 1021 & 0.499 & $f-k$ & 3.88 & 57 \\
\hline PI 266942 & 433 & 0.211 & $\mathrm{a}$ & 2.17 & 100 & PI 271333 & 1030 & 0.503 & $f-1$ & 3.58 & 63 \\
\hline PI 525103 & 522 & 0.255 & $\mathrm{ab}$ & 2.40 & 100 & PI 178882 & 1031 & 0.504 & $f-1$ & 3.58 & 60 \\
\hline PI 137854 & 560 & 0.274 & $\mathrm{~b}$ & 2.38 & 100 & PI 512413 & 1064 & 0.520 & $f-1$ & 4.53 & 25 \\
\hline PI 439746 & 636 & 0.311 & bc & 3.05 & 75 & PI 255947 & 1081 & 0.528 & $f-1$ & 4.18 & 38 \\
\hline PI 273442 & 640 & 0.313 & $b-d$ & 3.13 & 81 & PI 344338 & 1086 & 0.531 & $f-1$ & 3.95 & 40 \\
\hline PI 420180 & 655 & 0.320 & $\mathrm{~b}-\mathrm{e}$ & 2.55 & 88 & PI 527386 & 1092 & 0.533 & $f-1$ & 4.28 & 14 \\
\hline PI 525125 & 662 & 0.324 & $\mathrm{~b}-\mathrm{e}$ & 2.98 & 67 & PI 125952 & 1092 & 0.533 & $\mathrm{f}-1$ & 3.70 & 64 \\
\hline PI 323427 & 668 & 0.326 & $\mathrm{c}-\mathrm{e}$ & 2.90 & 88 & PI 304743 & 1103 & 0.539 & $g-1$ & 4.40 & 44 \\
\hline PI 344303 & 673 & 0.329 & $\mathrm{c}-\mathrm{e}$ & 2.83 & 87 & PI 181941 & 1116 & 0.545 & g-1 & 4.15 & 46 \\
\hline PI 304746 & 681 & 0.333 & $\mathrm{c}-\mathrm{e}$ & 3.00 & 81 & PI 164974 & 1126 & 0.550 & $\mathrm{~h}-1$ & 3.83 & 40 \\
\hline PI 176936 & 701 & 0.342 & de & 3.17 & 73 & PI 446929 & 1128 & 0.551 & $\mathrm{~h}-1$ & 4.50 & 14 \\
\hline PI 304747 & 717 & 0.350 & $d-f$ & 3.18 & 93 & PI 136188 & 1132 & 0.553 & $\mathrm{~h}-1$ & 4.63 & 21 \\
\hline PI 244714 & 779 & 0.381 & $d-f$ & 2.80 & 78 & PI 344335 & 1134 & 0.554 & $\mathrm{~h}-1$ & 4.05 & 43 \\
\hline PI 344068 & 785 & 0.383 & $d-f$ & 3.03 & 87 & PI 313974 & 1142 & 0.558 & $\mathrm{~h}-1$ & 4.65 & 56 \\
\hline PI 525113 & 804 & 0.393 & $d-g$ & 3.25 & 69 & PI 369161 & 1142 & 0.558 & $\mathrm{~h}-1$ & 4.15 & 14 \\
\hline PI 178880 & 806 & 0.394 & $\mathrm{~d}-\mathrm{g}$ & 3.58 & 63 & PI 177348 & 1143 & 0.558 & $\mathrm{~h}-1$ & 4.80 & 8 \\
\hline PI 183256 & 819 & 0.400 & $\mathrm{~d}-\mathrm{g}$ & 3.40 & 67 & PI 207659 & 1151 & 0.562 & $\mathrm{~h}-1$ & 3.98 & 50 \\
\hline PI 169359 & 820 & 0.401 & $\mathrm{~d}-\mathrm{g}$ & 4.02 & 40 & AM 21185 & 1154 & 0.564 & $\mathrm{~h}-1$ & 3.53 & 63 \\
\hline PI 140831 & 840 & 0.410 & $\mathrm{~d}-\mathrm{g}$ & 3.50 & 67 & AM 26051 & 1178 & 0.575 & $\mathrm{~h}-1$ & 4.03 & 47 \\
\hline PI 439747 & 862 & 0.421 & $\mathrm{~d}-\mathrm{h}$ & 3.40 & 63 & PI 614359 & 1181 & 0.577 & $\mathrm{i}-1$ & 3.63 & 57 \\
\hline PI 614441 & 876 & 0.428 & $\mathrm{~d}-\mathrm{h}$ & 3.33 & 67 & PI 169323 & 1182 & 0.577 & $\mathrm{i}-1$ & 4.43 & 20 \\
\hline PI 531305 & 877 & 0.428 & $\mathrm{~d}-\mathrm{h}$ & 3.63 & 50 & PI 470252 & 1188 & 0.580 & $\mathrm{i}-1$ & 4.03 & 44 \\
\hline PI 261760 & 886 & 0.433 & $\mathrm{~d}-\mathrm{i}$ & 3.25 & 81 & PI 175668 & 1205 & 0.589 & $\mathrm{i}-1$ & 4.45 & 25 \\
\hline PI 167044 & 897 & 0.438 & $\mathrm{~d}-\mathrm{i}$ & 3.13 & 63 & PI 419220 & 1242 & 0.607 & $\mathrm{j}-1$ & 4.55 & 27 \\
\hline PI 174137 & 897 & 0.438 & $\mathrm{~d}-\mathrm{i}$ & 4.10 & 33 & PI 126020 & 1267 & 0.619 & $\mathrm{j}-1$ & 4.90 & 15 \\
\hline PI 210077 & 899 & 0.439 & $\mathrm{~d}-\mathrm{j}$ & 3.18 & 69 & PI 207662 & 1297 & 0.634 & $\mathrm{j}-1$ & 4.88 & 6 \\
\hline PI 169340 & 912 & 0.446 & $\mathrm{~d}-\mathrm{j}$ & 4.05 & 46 & PI 182773 & 1300 & 0.635 & $\mathrm{j}-1$ & 4.40 & 31 \\
\hline PI 177362 & 918 & 0.449 & $\mathrm{~d}-\mathrm{j}$ & 3.45 & 69 & PI 176503 & 1308 & 0.639 & $j-m$ & 4.45 & 25 \\
\hline PI 357152 & 921 & 0.450 & $\mathrm{~d}-\mathrm{k}$ & 3.13 & 67 & PI 614578 & 1311 & 0.641 & $j-m$ & 4.33 & 31 \\
\hline PI 370021 & 933 & 0.456 & $\mathrm{~d}-\mathrm{k}$ & 2.97 & 75 & PI 220170 & 1321 & 0.645 & $\mathrm{j}-\mathrm{m}$ & 4.07 & 33 \\
\hline PI 143233 & 937 & 0.458 & $\mathrm{~d}-\mathrm{k}$ & 4.20 & 42 & PI 446931 & 1321 & 0.646 & $j-m$ & 4.90 & 7 \\
\hline PI 344401 & 944 & 0.461 & $\mathrm{~d}-\mathrm{k}$ & 3.55 & 57 & PI 182943 & 1334 & 0.652 & $\mathrm{j}-\mathrm{m}$ & 4.70 & 13 \\
\hline PI 210541 & 950 & 0.464 & $\mathrm{e}-\mathrm{k}$ & 3.35 & 67 & PI 176506 & 1343 & 0.656 & $\mathrm{k}-\mathrm{m}$ & 4.05 & 57 \\
\hline PI 618846 & 952 & 0.465 & $\mathrm{e}-\mathrm{k}$ & 3.98 & 50 & PI 222097 & 1357 & 0.663 & $\mathrm{k}-\mathrm{m}$ & 4.73 & 14 \\
\hline PI 224770 & 960 & 0.469 & $\mathrm{e}-\mathrm{k}$ & 3.63 & 60 & PI 543752 & 1361 & 0.665 & $\mathrm{k}-\mathrm{m}$ & 4.10 & 38 \\
\hline PI 288984 & 979 & 0.478 & $\mathrm{e}-\mathrm{k}$ & 4.23 & 30 & AM 13266 & 1381 & 0.675 & $\mathrm{k}-\mathrm{m}$ & 4.90 & 0 \\
\hline PI 531306 & 981 & 0.479 & $\mathrm{e}-\mathrm{k}$ & 3.38 & 80 & PI 179669 & 1390 & 0.679 & $\operatorname{lm}$ & 4.50 & 36 \\
\hline PI 211966 & 995 & 0.486 & $\mathrm{f}-\mathrm{k}$ & 4.37 & 33 & PI 169372 & 1419 & 0.693 & $\operatorname{lm}$ & 4.33 & 33 \\
\hline PI 176515 & 998 & 0.487 & $\mathrm{f}-\mathrm{k}$ & 3.65 & 56 & PI 441987 & 1453 & 0.710 & $\operatorname{lm}$ & 4.48 & 27 \\
\hline PI 162668 & 1001 & 0.489 & $\mathrm{f}-\mathrm{k}$ & 4.33 & 33 & PI 618822 & 1500 & 0.733 & $1-n$ & 4.70 & 13 \\
\hline PI 175676 & 1004 & 0.490 & $\mathrm{f}-\mathrm{k}$ & 3.73 & 56 & PI 93800 & 1664 & 0.813 & $\mathrm{mn}$ & 5.00 & 0 \\
\hline PI 344330 & 1007 & 0.492 & $\mathrm{f}-\mathrm{k}$ & 3.83 & 50 & Athena & 1746 & 0.853 & $\mathrm{n}$ & 5.00 & 0 \\
\hline Dinero & 1016 & 0.496 & $\mathrm{f}-\mathrm{k}$ & 5.00 & 0 & & & & & & \\
\hline
\end{tabular}

${ }^{\mathrm{z}}$ Each plant in the experiment was inoculated with $1 \mathrm{~mL}$ zoospore suspension $\left(1 \times 10^{4}\right.$ zoospores $\left./ \mathrm{mL}\right)$ of $P$. capsici.

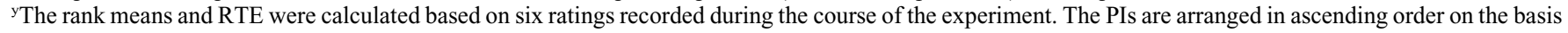
of their rank mean. Rank means and RTE followed by the same letter are not significantly different $(P=0.05)$.

${ }^{x}$ Ratings are the mean final ratings recorded $21 \mathrm{~d}$ after inoculation.

whe percentage of surviving plants is based on the total number of plants alive $21 \mathrm{~d}$ after inoculation from all four replications.

176940, PI 344069, PI 266942, PI 525103, and PI 137854 (Table 3). All of these PIs have a Middle Eastern origin, with the exception of PI 266942, which was obtained from Japan.

Third seedling screen. Disease development was very rapid on the susceptible cultivar Athena and plant death occurred within 2 weeks after inoculation for all plants (Table 4). Although disease development appeared to be a bit slower on the rootstock cultivar Dinero, overall it was not significantly different from 'Athena' (Table 4). Disease development was significantly slower and less severe on 23 PIs based on mean ranks and RTEs compared with the susceptible cultivar Athena (Table 4). Ten PIs had greater than $80 \%$ of the plants survive. Based on disease development over time as indicated by RTE, PI 420180 and PI 344069 were the most resistant PIs in this trial. PI 176940, PI 525103, and PI 266942 all had greater than $80 \%$ of the plants survive and disease development was significantly slower on these PIs compared with the susceptible cultivar Athena. Disease development was slower on PI 323427 when compared with the checks (Table 4) based on the rank means. However, $56 \%$ of the plants of these PIs succumbed to crown rot by the end of the experiment.

Confirming resistance in $S_{1}$ generation. Disease development was very rapid on the susceptible cultivar Athena based on mean ranks and percent survivors (Table 5). The $S_{1}$ generation of PI 176940, PI 176936, and PI 420180 had significantly lower ranks and more survivors than Athena when inoculated with the melon isolate of $P$. capsici indicating that resistant lines can be developed from these PI. Similarly, these three PI were also significantly more resistant than 'Athena' to RCZ-11 (zucchini isolate), WLB-8 (watermelon isolate), or a mixture of five isolates (Fig. 1). However, the $S_{1}$ generation of PI 266942 was highly susceptible.

\section{Discussion}

The three seedling screenings identified potential sources of resistance to crown rot caused by $P$. capsici in $C$. melo accessions. To our knowledge, this is the first time accessions of $C$. melo have been evaluated for resistance to $P$. capsici. The first seedling screen was used to quickly eliminate accessions showing no potential for resistance and the latter two screens provided a more thorough analysis of the accessions with potential resistance. A significant correlation $\left(r^{2}=0.63\right.$, 
$P \leq 0.0004$ ) between the rankings (RTE) of the 25 PIs in the second and the third seedling screens was observed. Similarly, the ratings $\left(r^{2}=0.62, P \leq 0.0006\right)$ and the percent survivors $\left(r^{2}=0.58, P \leq 0.0017\right)$ were also significantly correlated for the 25 PIs in the second and the third seedling screens.

In both seedling screens 2 and 3, several PIs performed consistently and can be considered as potential sources of resistance to crown rot. PI 420180 originally collected from Japan had greater than $80 \%$ of the plants survive in the two screens and the disease development over time was significantly slower $(P \leq 0.0001)$ compared with the susceptible cultivar Athena. Several PIs collected in Turkey (PI 344068, PI 344069, and PI 176940) did well in both screens. Similarly, PI 525103 and PI 525125 originally collected from Egypt can also be considered as potential sources of resistance to crown rot (Tables 3 and 4). Muskmelon (C. melo) fruits are known to be susceptible to fruit rot caused by $P$. capsici; however, resistance to fruit rot has not yet been identified in melon (Ando et al., 2009). It would be interesting to determine if the crown rot-resistant PI identified in this study might also have resistance to fruit rot.

Table 4. Development of crown rot over time (Rank mean), relative treatment effects (RTE), average final rating, and number of survivors of select Cucumis melo PIs inoculated with Phytophthora capsici in the greenhouse seedling screen $3 .^{2}$

\begin{tabular}{|c|c|c|c|c|c|}
\hline PI & Country & Rank mean ${ }^{\mathrm{y}}$ & RTE & Rating $(0-5)^{\mathrm{x}}$ & Survivors $(\%)^{\mathrm{w}}$ \\
\hline$\overline{\text { PI } 420180}$ & Japan & 122.6 & $0.141 \mathrm{a}$ & 0.3 & 100 \\
\hline PI 344069 & Turkey & 193.8 & $0.224 \mathrm{ab}$ & 0.8 & 94 \\
\hline PI 266942 & Japan & 261.1 & $0.302 \mathrm{bc}$ & 1.6 & 81 \\
\hline PI 323427 & Austria & 266.7 & $0.308 \mathrm{c}$ & 3.9 & 44 \\
\hline PI 261760 & Belgium & 274.3 & $0.317 \mathrm{c}$ & 1.9 & 75 \\
\hline PI 439746 & Cyprus & 324.5 & $0.375 \mathrm{~cd}$ & 2.3 & 75 \\
\hline PI 176936 & Turkey & 336.8 & $0.389 \mathrm{~cd}$ & 2.0 & 94 \\
\hline PI 344068 & Turkey & 341.0 & $0.394 \mathrm{~d}$ & 1.2 & 100 \\
\hline PI 344303 & Turkey & 367.1 & $0.424 \mathrm{~d}$ & 2.1 & 81 \\
\hline PI 525125 & Egypt & 378.7 & $0.438 \mathrm{~d}$ & 1.4 & 94 \\
\hline PI 344330 & Turkey & 387.2 & $0.448 \mathrm{~d}$ & 2.6 & 69 \\
\hline PI 176940 & Turkey & 391.2 & $0.452 \mathrm{de}$ & 1.7 & 94 \\
\hline PI 525103 & Egypt & 434.6 & $0.502 \mathrm{de}$ & 1.7 & 94 \\
\hline PI 273442 & Canada & 437.1 & $0.505 \mathrm{de}$ & 4.0 & 44 \\
\hline PI 370021 & India & 459.2 & $0.531 \mathrm{de}$ & 1.4 & 94 \\
\hline PI 344335 & Turkey & 465.1 & $0.538 \mathrm{de}$ & 3.7 & 44 \\
\hline PI 183256 & Saudi Arabia & 465.3 & $0.538 \mathrm{de}$ & 2.7 & 63 \\
\hline PI 244714 & Turkey & 481.2 & $0.556 \mathrm{de}$ & 2.2 & 75 \\
\hline PI 304747 & El Salvador & 481.8 & $0.557 \mathrm{de}$ & 4.6 & 13 \\
\hline PI 93800 & China & 488.2 & $0.565 \mathrm{de}$ & 2.3 & 69 \\
\hline PI 614441 & India & 500.3 & $0.579 \mathrm{de}$ & 2.2 & 69 \\
\hline PI 531306 & Soviet Union & 513.9 & $0.594 \mathrm{de}$ & 1.8 & 81 \\
\hline PI 137854 & Iran & 525.1 & $0.607 \mathrm{e}$ & 2.6 & 63 \\
\hline PI 304746 & El Salvador & 629.9 & $0.728 \mathrm{f}$ & 4.3 & 19 \\
\hline Dinero & & 656.2 & $0.759 \mathrm{f}$ & 4.6 & 13 \\
\hline AM 13266 & Spain & 676.8 & $0.783 \mathrm{f}$ & 4.9 & 6 \\
\hline Athena & & 818.4 & $0.946 \mathrm{f}$ & 5.0 & 0 \\
\hline
\end{tabular}

${ }^{\mathrm{z}}$ Each plant in the experiment was inoculated with a $1 \mathrm{~mL}$ zoospore suspension $\left(1 \times 10^{4}\right.$ zoospores $\left./ \mathrm{mL}\right)$ of P. capsici. There were four plants per replications and four replications per PI.

${ }^{\mathrm{y}}$ Rank means and RTE were calculated based on eight ratings recorded during the course of the experiment. The PIs are arranged in ascending order on the basis of their rank mean. RTE for each PI followed by the same letter are not significantly different $(P=0.05)$.

${ }^{x}$ Ratings are the mean final ratings recorded $36 \mathrm{~d}$ after inoculation.

${ }^{\mathrm{w}}$ The percentage of surviving plants is based on the total number of plants alive in all four replications.

Evaluation of the $\mathrm{S}_{1}$ generation of three PIs (PI 176940, PI 176936, and PI 420180) against different $P$. capsici isolates and a mixture of isolates further confirmed them as potential sources of resistance (Fig. 1). We also continued to collect data from this experiment for a little longer than our previous experiments to make sure that the resistant accessions were indeed resistant. The resistant plants of these three PIs that survived the inoculations were transferred to larger pots and all of them produced fruit to generate $\mathrm{S}_{2}$ seed. This also indicates that highly resistant germplasm can be developed from these sources. However, further screening and careful selection from the original PIs using higher inoculum concentrations will be needed to develop highly resistant lines. In this experiment, the $\mathrm{S}_{1}$ generation of PI 266942 was highly susceptible. It is possible that the seeds of the $S_{1}$ generation could have been from a plant that was an escape in the previous screen. In these experiments, the rootstock cultivar Dinero was not as susceptible to the melon isolate compared with the zucchini or watermelon isolate. It is well known that variability in level of virulence exists among the individual $P$. capsici isolates (Granke et al., 2012; Quesada-Ocampo et al., 2010; Quesada-Ocampo and Hausbeck, 2010). This was one of the reasons we chose to use a mixture of isolates in our screens.

We also used a mixture of isolates in these experiments because in most commercial vegetable fields, several different crops belonging to various families are grown. For example, a pepper crop is followed by cucumbers in Florida or a watermelon crop is planted on the same bed after a tomato crop. $P$. capsici is known to infect all these crops (Granke et al., 2012; Hausbeck and Lamour, 2004). The host plant from which a $P$. capsici isolate is collected does not define the host specificity or the virulence of the isolate on a given crop. For example, $P$. capsici isolates collected from bean were observed to be more aggressive on zucchini fruit than the cucurbit isolates (Quesada-Ocampo et al., 2010). In recent studies, Granke et al. (2012) also evaluated the virulence of over 100 isolates and reported that $P$. capsici isolates from fabaceous hosts were very

Table 5. Development of crown rot caused by three individual and a mixture of five isolates ${ }^{\mathrm{z}}$ of Phytophthora capsici on select $\mathrm{S}_{1}$ generation of Cucumis melo PIs.

\begin{tabular}{|c|c|c|c|c|c|c|c|c|c|c|c|c|c|c|c|c|}
\hline \multirow[b]{2}{*}{ Melon } & \multicolumn{4}{|c|}{$\begin{array}{l}\text { Melon isolate } \\
\text { (MWM-1) }\end{array}$} & \multicolumn{4}{|c|}{$\begin{array}{c}\text { Isolate } \\
\text { RCZ-11 }\end{array}$} & \multicolumn{4}{|c|}{$\begin{array}{l}\text { Isolate } \\
\text { WLB-8 }\end{array}$} & \multicolumn{4}{|c|}{$\begin{array}{c}\text { Mix of } \\
\text { five isolates }\end{array}$} \\
\hline & $\begin{array}{l}\text { Mean } \\
\text { rank }^{y}\end{array}$ & & $\begin{array}{l}\text { Mean } \\
\text { rating } \\
(0-5)^{x}\end{array}$ & $\begin{array}{c}\text { Survivors } \\
(\%)^{\mathrm{w}}\end{array}$ & $\begin{array}{c}\text { Mean } \\
\text { rank }\end{array}$ & & $\begin{array}{l}\text { Mean } \\
\text { rating } \\
(0-5)\end{array}$ & $\begin{array}{c}\text { Survivors } \\
(\%)\end{array}$ & $\begin{array}{c}\text { Mean } \\
\text { rank }\end{array}$ & & $\begin{array}{c}\text { Mean } \\
\text { rating } \\
(0-5)\end{array}$ & $\begin{array}{c}\text { Survivors } \\
(\%)\end{array}$ & $\begin{array}{c}\text { Mean } \\
\text { rank }\end{array}$ & & $\begin{array}{l}\text { Mean } \\
\text { rating } \\
(0-5)\end{array}$ & $\begin{array}{c}\text { Survivors } \\
(\%)\end{array}$ \\
\hline$\overline{\text { PI } 176936}$ & 116 & $\mathrm{~b}$ & 2.0 & 89 & 110 & $\mathrm{bc}$ & 2.5 & 85 & 96 & $\mathrm{c}$ & 2.0 & 88 & 65 & $\mathrm{~d}$ & 1.3 & 100 \\
\hline PI 176940 & 92 & $\mathrm{~b}$ & 1.1 & 100 & 87 & $\mathrm{~cd}$ & 1.9 & 100 & 93 & $\mathrm{c}$ & 1.8 & 94 & 103 & $\mathrm{c}$ & 1.7 & 100 \\
\hline PI 420180 & 102 & $\mathrm{~b}$ & 1.3 & 100 & 72 & $\mathrm{~d}$ & 1.1 & 100 & 94 & $\mathrm{c}$ & 2.5 & 88 & 106 & $\mathrm{bc}$ & 1.8 & 94 \\
\hline PI 266942 & 157 & $\mathrm{a}$ & 4.0 & 67 & 123 & $\mathrm{~b}$ & 3.8 & 80 & 125 & $\mathrm{~b}$ & 4.2 & 50 & 139 & $\mathrm{~b}$ & 4.8 & 13 \\
\hline Dinero & 89 & $\mathrm{~b}$ & 1.8 & 94 & 132 & $\mathrm{~b}$ & 4.2 & 31 & 120 & $\mathrm{bc}$ & 3.5 & 38 & 111 & $\mathrm{~b}$ & 2.7 & 63 \\
\hline Athena & 166 & $\mathrm{a}$ & 4.0 & 40 & 198 & $\mathrm{a}$ & 5.0 & 0 & 194 & $\mathrm{a}$ & 4.9 & 7 & 197 & $\mathrm{a}$ & 5.0 & 0 \\
\hline
\end{tabular}

${ }^{\mathrm{z}}$ Each plant in the experiment was inoculated with a $1 \mathrm{~mL}$ zoospore suspension $\left(1 \times 10^{4}\right.$ zoospores/mL $)$ of $P$. capsici. There were four plants per replications and four replications per PI for each of the isolates or the mixture.

${ }^{\mathrm{y}}$ Rank means were calculated based on 10 ratings recorded twice 1 week during the course of the experiment. The PIs are arranged in ascending order on the basis of their rank mean. Rank means for each PI followed by the same letter are not significantly different $(P=0.05)$.

${ }^{\mathrm{x}}$ Ratings are the mean final ratings recorded 7 weeks after inoculation.

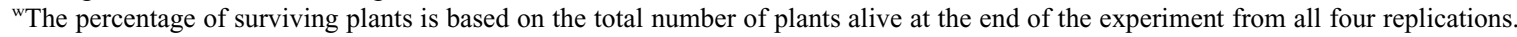




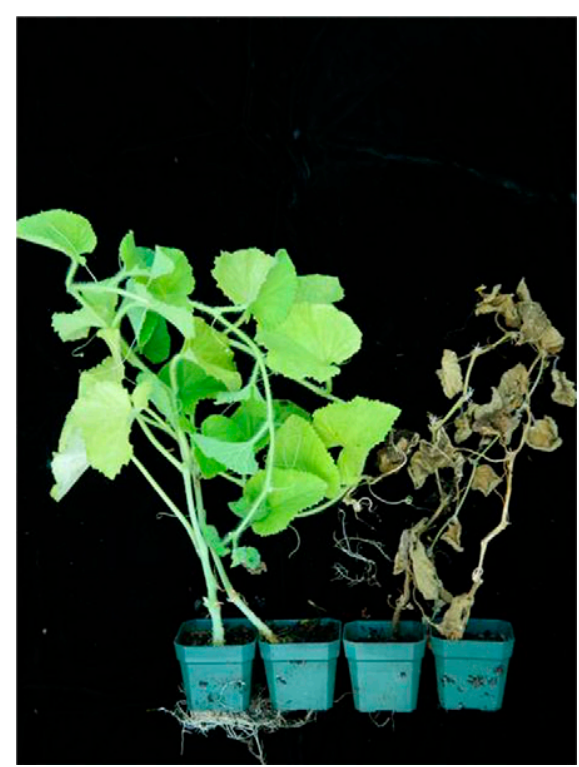

Fig. 1. Crown rot resistant selection of Cucumis melo PI $176940\left(\mathrm{~S}_{1}\right)$ on the left compared with susceptible cultivar Athena on the right against a mixture of five isolates of Phytophthora capsici. All the plants of the susceptible cultivar Athena died as a result of severe crown rot.

aggressive on cucurbits. It was also suggested by Granke et al. (2012) that a highly aggressive isolate of $P$. capsici should be used in evaluations regardless of the host from which it was isolated. Because of this variability in aggressiveness of $P$. capsici isolates, we used a mixture of isolates to screen for potential sources of resistance to crown rot. Further studies using individual isolates from various crops, especially from fabaceous hosts on resistant melon PI to determine the existence of races as described for peppers by Glosier et al. (2008), needs to be conducted.

Variation in levels of resistance to $P$. capsici inoculation was observed among plants within all PIs. This type of variability has been observed by other researchers during evaluations of cucurbit germplasm for their response to various viral, fungal, and bacterial diseases (Boyhan et al., 1992; Davis et al., 2007; Gillaspie and Wright, 1993; Gusmini et al., 2005; Kousik et al., 2009; Strange et al., 2002; Wechter et al., 2011). One of the reasons suggested for this variability is that most of the accessions in the collection may have been increased by open pollination, thus providing the chance for cross-pollination of some of the accessions (Gillaspie and Wright, 1993; Strange et al., 2002). In addition, these accessions were originally collected in the open from various regions of the world and may have been cross-pollinated before collection. Because of this existing variability within PIs, it is essential to develop homozygous-resistant lines within each PI by careful selection and screening of the existing PIs, which are potential sources of resistance. Hence, we also evaluated the $S_{1}$ generation of some of the most resistant PI. The evaluations of the $\mathrm{S}_{1}$ generation also indicated that resistant sources can be developed from these PI relatively easily for use in breeding programs. Presently, we are making pure line selections within the most resistant PIs to develop crown rot-resistant germplasm.

In summary, the present study identified several potential sources of resistance to crown rot caused by $P$. capsici in melon $(C$. melo) accessions for use in breeding programs. Highly resistant germplasm can be developed from these sources by careful screening and self-pollination of individual resistant plants within such PI. These sources of resistance will be useful in breeding for resistance to crown rot and development of resistant rootstocks.

\section{Literature Cited}

Akritas, M.G. and E. Brunner. 1997. A unified approach to rank tests for mixed models. J. Statist. Plann. Inference 81:249-277.

Ando, K., S. Hammar, and R. Grumet. 2009. Agerelated resistance of diverse cucurbit fruit to infection by Phytophthora capsici. J. Amer. Soc. Hort. Sci. 134:176-182.

Babadoost, M. 2005. Phytophthora blight of cucurbits. The Plant Health Instructor. DOI:10.1094/ PHI-I-2005-0429-01.

Babadoost, M. and S.Z. Islam. 2003. Fungicide seed treatment effects on seedling damping-off of pumpkin caused by Phytophthora capsici. Plant Dis. 87:63-68.

Babadoost, M. and T.A. Zitter. 2009. Fruit rots of pumpkin: A serious threat to the pumpkin industry. Plant Dis. 93:772-782.

Boyhan, G., J.D. Norton, B.J. Jacobsen, and B.R. Abrahams. 1992. Evaluation of watermelon and related germplasm for resistance to zucchini yellow mosaic virus. Plant Dis. 76:251-252.

Brunner, E., S. Domhof, and F. Langer. 2002. Nonparametric analysis of longitudinal data in factorial experiments. New York, NY.

Chavez, D.J., E.A. Kabelka, and J.X. Chaparro. 2011. Screening of Cucurbita moschata Duchesne germplasm for crown rot resistance to Floridian isolates of Phytophthora capsici Leonian. HortScience 46:536-540.

Davis, A.R., L. Levi, A. Tetteh, and T.C. Wehner. 2007. Evaluation of watermelon and related species for resistance to race $1 \mathrm{~W}$ powdery mildew. J. Amer. Soc. Hort. Sci. 132:790-795.

Erwin, D.C. and O.K. Ribeiro. 1996. Phytophthora diseases worldwide. American Phytopathological Society, St. Paul, MN.

French-Monar, R.D., J.B. Jones, and P.D. Roberts 2006. Characterization of Phytophthora capsici with roots of weeds on Florida vegetable farms. Plant Dis. 90:345-350.

Gevens, A.J., P.D. Roberts, R.J. McGovern, and T.A. Kucharek. 2008. Vegetable diseases caused by Phytophthora capsici in Florida. University of Florida, Extension Digital Information Source SP159. <http://edis.ifas.ufl. $\mathrm{edu} / \mathrm{vh} 045>$.

Gillaspie, A.G. and J.M. Wright. 1993. Evaluation of Citrullus sp. germplasm for resistance to watermelon mosaic virus 2. Plant Dis. 77:352354

Glosier, B.R., E.A. Ogundiwin, G.S. Sidhu, D.R Sischo, and J.R. Prince. 2008. A differential series of pepper (Capsicum annuum) lines delineates fourteen physiological races of Phytophthora capsici. Euphytica 162:23-30.

Granke, L.L., L.M. Quesada-Ocampo, and M.K. Hausbeck. 2012. Differences in virulence of Phytophthora capsici isolates from a worldwide collection on host fruits. Eur. J. Plant Pathol. 132:281-296.

Gubler, W.D. and R.M. Davis. 1996. Phytophthora root and crown rot, p. 19-20. In: Zitter, T.A., D.L. Hopkins, and C. E. Thomas (eds.). Compendium of cucurbit diseases. APS Press, St. Paul, MN.

Gusmini, G., R. Song, and T.C. Wehner. 2005. New sources of resistance to gummy stem blight in watermelon. Crop Sci. 45:582-588.

Hausbeck, M.K., J.M. Foster, and S.D. Linderman. 2012. Managing Phytophthora on cantaloupe, muskmelon and watermelon. 18 June 2012. $<$ http://www.veggies.msu.edu/Research/FS_ MelonPcap.pdf $>$.

Hausbeck, M.K. and K.H. Lamour. 2004. Phytophthora capsici on vegetable crops: Research progress and management challenges. Plant Dis. 88:1292-1303.

Henz, G.P. and M.F. Lima. 1998. Plantlet resistance of cucurbit cultivars to root rot caused by Phytophthora capsici. Pesquisa Agropecu. Bras. 33:853-859.

Jackson, K.L., J. Yin, and P. Ji. 2012. Sensitivity of Phytophthora capsici on vegetable crops in Georgia to mandipropamid, dimethomorph and cyazofamid. Plant Dis. 96:1337-1342.

Keinath, A.P. 2007. Sensitivity of populations of Phytophthora capsici from South Carolina to mefenoxam, dimethomorph, zoxamide, and cymoxanil. Plant Dis. 91:743-748.

Kousik, C.S., M.L. Adams, W.R. Jester, R. Hassell, H.F. Harrison, and G.J. Holmes. 2011. Effect of cultural practices and fungicides on Phytophthora fruit rot of watermelon in the Carolinas. Crop Prot. 30:888-894.

Kousik, C.S., S. Adkins, W.W. Turechek, and P.D. Roberts. 2009. Sources of resistance in U.S. plant introductions to watermelon vine decline caused by squash vein yellowing virus. HortScience 44:256-262.

Kousik, C.S., R.S. Donahoo, and R. Hassell. 2012. Resistance in watermelon rootstocks to crown rot caused by Phytophthora capsici. Crop Prot. $39: 18-25$.

Kousik, C.S. and R. Hassell. 2011. Evaluation of commercial melon rootstocks for tolerance to crown rot, 2010. Plant Disease Management Reports 5:V057.

Kousik, C.S. and A.P. Keinath. 2008. First report of insensitivity to cyazofamid among isolates of Phytophthora capsici from the southeastern United States. Plant Dis. 92:979.

Kousik, C.S. and J.A. Thies. 2007. Response of U.S. bottle gourd (Lagenaria siceraria) Plant Introductions to Phytophthora capsici. Proc. of the First International Phytophthora capsici conference. Islamorada, FL.

Kreutzer, W.A. 1937. A Phytophthora rot of cucumber fruit. Phytopathology 27:955.

Kreutzer, W.A., E.W. Bodine, and L.W. Durrell. 1940. Cucurbit diseases and rot of tomato fruit caused by Phytophthora capsici. Phytopathology 30:951-957.

Lamour, K.H. and M.K. Hausbeck. 2000. Mefenoxam insensitivity and the sexual stage of Phytophthora capsici in Michigan cucurbit fields. Phytopathology 90:396-400.

Lee, B.K., B.S. Kim, S.W. Chang, and B.K Hwang. 2001. Aggressiveness to pumpkin cultivars of isolates of Phytophthora capsici from pumpkin and pepper. Plant Dis. 85:497-500.

Lynch, L. and J. Carpenter. 1999. The economic impacts of banning methyl. Where do we need more research? Annual Research Conference on Methyl Bromide Alternatives and Emissions Reductions. <http://www.epa.gov/ozone/mbr/airc/ 1999/55lynchl.pdf $>$. 
Matheron, M.E. and M. Porchas. 2000. Comparison of five fungicides on development of root, crown, and fruit rot of Chile Pepper and recovery of Phytophthora capsici from Soil. Plant Dis. 84:1038-1043.

McGovern, R.J., J.P. Jones, D.J. Mitchell, R.A. Pluim, and P.R. Gilreath. 1993. Severe outbreak of Phytophthora blight and fruit rot of cucurbits in Florida. Phytopathology 83:1388 (Abstr.).

McGrath, M.T. 1996. Phytophthora fruit rot, p. 5354. In: Zitter, T.A., D.L. Hopkins, and C.E. Thomas (eds.). Compendium of cucurbit diseases. APS Press, St. Paul, MN.

Osteen, C. 2003. Methyl bromide phaseout proceeds: Users request exemptions. Amber Waves $1: 23-27$.

Padley L.D., Jr., P.D. Roberts, R. French, and E.A. Kabelka. 2008. Evaluation of Cucurbita pepo accessions for crown rot resistance to isolates of Phytophthora capsici. HortSci. 43:19961999.
Quesada-Ocampo, L.M., L.L. Granke, and M.K. Hausbeck. 2010. Differences in virulence of Phytophthora capsici isolates from a worldwide collection on zucchini fruits, p. 248-251. In: Thies, J.A., C.S. Kousik, and A. Levi (eds.). Proc. Cucurbitaceae 2010. American Society of Horticultural Science, Alexandria, VA.

Quesada-Ocampo, L.M. and M.K. Hausbeck. 2010. Resistance in tomato and wild relatives to crown and root rot caused by Phytophthora capsici. Phytopathology 100:619-627.

Ristaino, J.B., M. Madritch, C.L. Trout, and G. Parra. 1998. PCR amplification of ribosomal DNA for species identification in the plant pathogen genus Phytophthora. Appl. Environ. Microbiol. 64:948-954.

Shah, D.A. and L.V. Madden. 2004. Nonparametric analysis of ordinal data in designed factorial experiments. Phytopathology 94:33-43.

Strange, B.E., N. Guner, Z. Pesic-VanEsbroeck, and T.C. Wehner. 2002. Screening the water- melon germplasm collection for resistance to papaya ringspot virus type-W. Crop Sci. 42:1324-1330.

Thompkins, C.M. and C.M. Tucker. 1937. Phytophthora rot of honeydew melon. J. Agr. Res 54:933-944.

Tuset-Barrachina, J.J. 1977. Contribucion al conocimiento del genero Phytophthora De Bary en Espana. An. Inst. Nac. Invest. Agrarias, Proteccion veg. CRIDA (Levante). INIA 7: 11-106 [in Spanish].

Wechter, W.P., A. Levi, K.S. Ling, C.S. Kousik, and C.C. Block. 2011. Identification of resistance to Acidovorax avenae subsp. citrulli among melon (Cucumis spp.) plant introductions. HortScience 46:207-212.

Zhang, Z.G., Y.Q. Li, Y.C. Wang, and X.B. Zheng. 2006. Molecular detection of Phytophthora capsici in infected plant tissues, soil and water. Plant Pathol. 55:770 775 . 